\title{
Study on the Strategy of Supplier Classification Management
}

\author{
Ming Liu ${ }^{1, a}$ \\ ${ }^{1}$ School of Economics and Management, Weifang University, Weifang Shandong 261061, China; \\ aemail:wfuliuming@126.com
}

Keywords: Supplier management; Supplier classification; Material characteristics; Product green degree; Purchase risk

\begin{abstract}
In order to improve the performance of supplier management, and ensure the operation of supply chain, the enterprises should constitute differential management strategy to suppliers of different types. Distinguish from the previous way of two-dimensional classification, the paper subdivided the material by three dimensions, including cost value, product green degree and purchase risk. According to the characteristics of materials, suppliers can be classified into 6 types. The supplier management strategy of each type was analyzed in the paper, which includes management strategy and keynote, relationship strategy, supplier evaluation criteria. The study enriches the theory of supply chain and supplier management. The conclusion will play the role of guidance and reference to the actual supplier management of enterprises.
\end{abstract}

\section{Introduction}

For the enterprise, there are a large number of suppliers. If the enterprise used the same approach to manage them, the most complex and difficult situation must be considered. This would increase the cost and difficulty of supplier management. In order to ensure the reliability and reduce the cost of purchasing and supplier management, the enterprise should classify the supplier management. In view of this, based on the characteristics of materials, the article will investigate the classification of suppliers, and establish the differential management strategy, in order to improve the performance of supplier management in enterprise.

\section{Research status of supplier classification method}

At present, researches about supplier classification method are many. Svensson deemed that the supplier classification should be according to trade standards (such as market environment) and the relationship of supplier and cooperation [1]. Dyer studied on classification of strategic supplier, he divided the supplier into two parts. One is the essential supplier, while they didn't provide strategic value. The other is the value-added supplier. These suppliers can improve the core competitiveness of enterprise and enhance the product differentiation strategy [2]. Olsen and Ellram classified suppliers to 4 types, strategic supplier, bottleneck supplier, lever supplier and general supplier [3], as shown as figure 1.

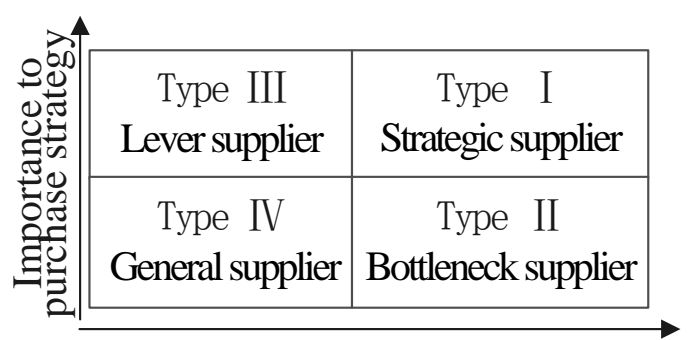

Difficulty of purchase management

Fig. 1 Olsen’s matrix of supplier classification

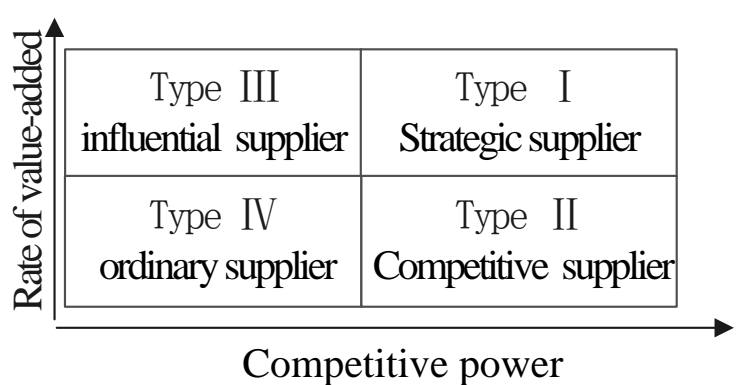

Fig. 2 Lin Yong's matrix of supplier classification 
Lin Yong replaced the two-dimensional in fig. 1 by value-added capability and competitive power of supplier, and classified suppliers into 4 types: strategic supplier, competitive supplier, influential supplier and ordinary supplier [4]. As shown as figure 2.

It flows that, only limited existing research considered factors of environment protection and market risk. Based on existing studies, the paper classified suppliers according to three aspects, including material's cost value, green degree and purchase risk

\section{Analysis of material purchasing characteristics}

With the rapid development of green supply chain, the enterprise did not only pay more attention to the relative importance of material on financial status, but also pay more attention to supply risk [5]. So, material's cost value, green degree and purchase risk were considered while classifying suppliers. That is different from the former approach.

Purchase risk. The purchase risk was defined as follows:

$$
X=f\left(x_{1}, x_{2}, \cdots, x_{m}\right)
$$

Wherein, $X=f\left(x_{1}, x_{2}, \cdots, x_{m}\right)$ means the main factors affecting purchase risk, such as: the difficulty of material procurement, the substitution of material, the number of suppliers, the reliability of supplier, supplier's increment ability, status of supplier, the probability of self-made and outsourcing, etc.

Purchase risk is the external influence factors of purchase performance. It decided the conversion cost of material, and whether the material can supply sufficiently or not [6]. The increase of purchase risk will increase the difficulty of purchase management, which will cause the decline of bargaining power and control of enterprise.

Product green degree. The product green degree was defined as follows:

$$
Y=g\left(y_{1}, y_{2}, \cdots, y_{n}\right)
$$

Wherein, $Y=g\left(y_{1}, y_{2}, \cdots, y_{n}\right)$ means various influence factors of product green degree, such as: environmental load of unit product in manufacturing process, the damage to environment in process of re-process, application, scraping and recycling.

Cost value. The The cost value was defined as follows:

$$
Z=h\left(z_{1}, z_{2}, \cdots, z_{r}\right)
$$

Wherein, $Z=h\left(z_{1}, z_{2}, \cdots, z_{r}\right)$ means various influence factors of material's importance, such as: total volume of purchase, the proportion of purchase sum, influence to the percent of pass, loss of enterprise when the material is shortage, etc.

The cost value of material can measure its contribution to final product, and its effect to enterprise's financial profit [7]. The division can help the allocation of material. For the purchase strategy, more attention should be paid to the material with large contribution and big effect to profit of enterprise.

For the three functions above, the dates can be got by principal component analysis, cluster analysis or other statistics [8]. $\mathrm{X}^{*}, \mathrm{Y}^{*}$ and $\mathrm{Z}^{*}$ were defined as the critical date of each variable. The materials, that are sufficient and in a buyer's market, are marked with $\mathrm{X} 1\left(\mathrm{X} 1 \leqslant \mathrm{X}^{*}\right)$. Materials that are lack and in a seller's market can be marked with $\mathrm{X} 2\left(\mathrm{X} 2>\mathrm{X}^{*}\right)$. Also, the materials with high green level and small environmental risk can be marked with $\mathrm{Y} 2\left(\mathrm{Y} 2 \geqslant \mathrm{Y}^{*}\right)$. Materials with low green level can be marked with $\mathrm{Y} 1\left(\mathrm{Y} 1<\mathrm{Y}^{*}\right)$. Materials with little cost value can be marked with $\mathrm{Z} 1\left(\mathrm{Z} 1 \leqslant \mathrm{Z}^{*}\right)$. Materials with high cost value can be marked with $\mathrm{Z} 2\left(\mathrm{Z} 2>\mathrm{Z}^{*}\right)$.

By assembling factors above, the materials can be divided into 8 types, as shown as figure 3 . 


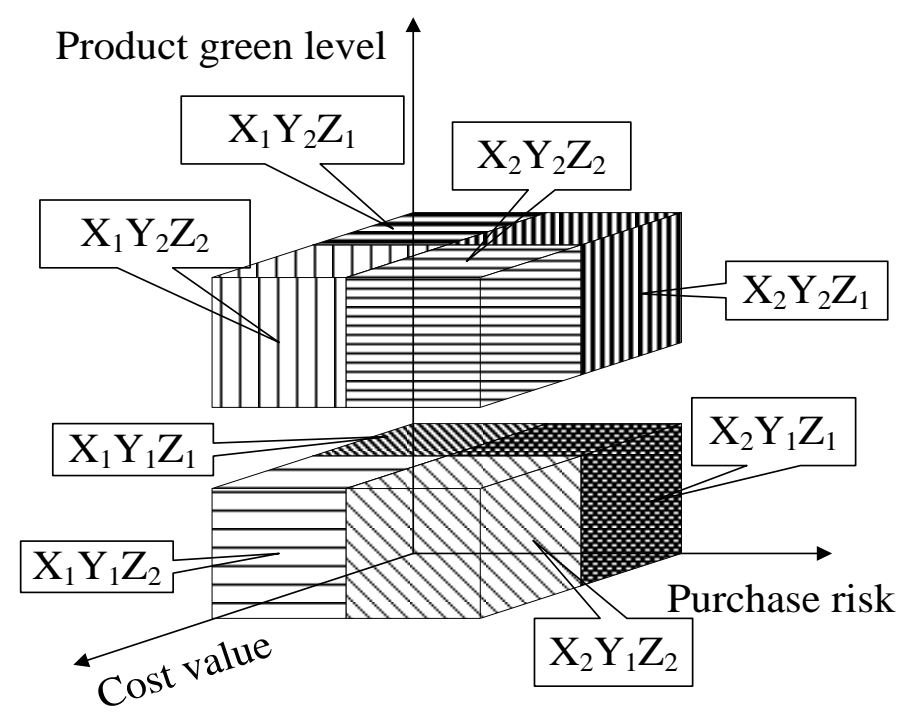

Fig. 3 Materials classification

\section{Strategy of supplier classification management based on material characteristics}

In order to guarantee the production and reduce the purchase cost, the suppliers' strategic positions must be constituted. According to the characteristics of materials, the supplier management strategy can be divided into 6 types, as shown as figure 4 .

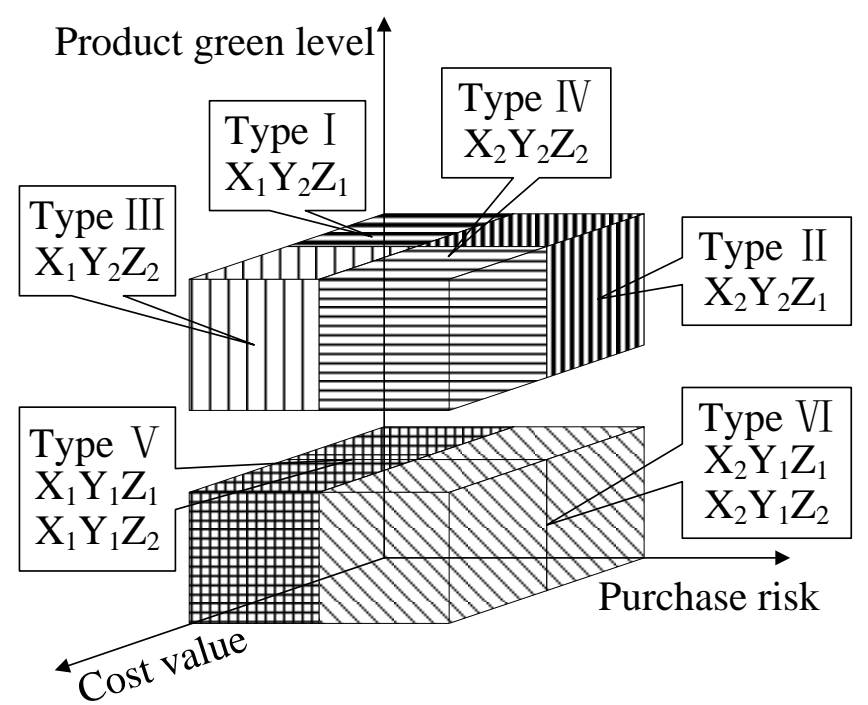

Fig. 4 Classification of supplier clasmanagement strategy

Type I: the supplier supplied ordinary materials with low value and procurement risk, but high green degree. This kind of materials is in a buyer's market. The enterprise just need keep general trade relationship with suppliers. The key of supplier management contains product standardization and inventory optimization. These can reduce the kinds and stock of material, which will improve business efficiency and minimize management costs.

Type II: the supplier supplied bottleneck materials with low value, high green degree and purchase risk. The supplier management must focuses on reliability of supply firstly, and business efficiency secondly. In order to reduce or even eliminate the bottleneck materials, the enterprise should develop new suppliers actively and standardize the material [9]. Thus materials should keep a higher order quantity and safety inventory.

Type III: the supplier supplied commonly materials with low purchase risk, high value and green degree. The goal of supplier management is minimization cost of purchase and inventory. The 
enterprise must be dominant in the partnership, and let suppliers realize the existence of competition [10]. The key of supplier management contains brand management, economic order quantity, minimization of purchase cost.

Type IV: the supplier supplied strategic materials with high value, green degree and purchase risk. This kind of materials is in a seller's market, there are only limited qualified suppliers. So, the enterprise should establish long-term strategic cooperative partnership with suppliers. The supplier management must focus on the reliability of supply and quality, which contains demand forecast, inventory monitoring, logistics support and advance projects of emergency.

Type V: the supplier supplied materials with low green degree and purchase risk. There are many of these suppliers, but the green level is low generally. The supplier management should focus on cost reduction and monitoring of supplies. The green threshold must be conformed. To avoid the material turned into bottleneck material when new regulations were published, the enterprise must improve product's green degree, by researching and developing actively.

Type VI: the supplier supplied materials with low green degree ,but high purchase risk. In order to control supply risk and guarantee the security of supply, the supplier's management should take a flexible win-win strategy. At the same time, the enterprise should take part in the supplier's production improvement actively, or research and development independently. The plan of supply must be rigorous, especially the quantity and time of delivery. The preparations of emergency must be ready.

Table 1 described the projects of each supplier management strategy as follows.

Table 1 Supplier management strategy combination

\begin{tabular}{|c|c|}
\hline $\begin{array}{c}\text { Supplier } \\
\text { types }\end{array}$ & Supplier management strategy \\
\hline $\begin{array}{l}\text { Type I } \\
\left(\mathrm{X}_{1} \mathrm{Y}_{2} \mathrm{Z}_{1}\right)\end{array}$ & $\begin{array}{l}\text { (1) Management strategy: minimization of management cost. } \\
\text { (2) Supplier relationship: general trade relationship. } \\
\text { (3)Performance evaluation criteria: economical order quantity and business } \\
\text { efficiency. }\end{array}$ \\
\hline $\begin{array}{c}\text { Type II } \\
\left(\mathrm{X}_{2} \mathrm{Y}_{2} \mathrm{Z}_{1}\right)\end{array}$ & $\begin{array}{l}\text { (1) Management strategy: minimization of purchase cost. } \\
\text { (2) Supplier relationship: dominant trade relationship. } \\
\text { (3) Performance evaluation criteria: reliability of supply and business efficiency. }\end{array}$ \\
\hline $\begin{array}{c}\text { Type III } \\
\left(\mathrm{X}_{1} \mathrm{Y}_{2} \mathrm{Z}_{2}\right)\end{array}$ & $\begin{array}{l}\text { (1) Management strategy: minimization of purchase cost. } \\
\text { (2) Supplier relationship: general partnership. } \\
\text { (3)Performance evaluation criteria: minimization cost of purchase and inventory. }\end{array}$ \\
\hline $\begin{array}{c}\text { Type IV } \\
\left(\mathrm{X}_{2} \mathrm{Y}_{2} \mathrm{Z}_{2}\right)\end{array}$ & $\begin{array}{l}\text { (1) Management strategy: win-win strategy. } \\
\text { (2) Supplier relationship: strategic cooperative partnership. } \\
\text { (3)Performance evaluation criteria: long-term reliability of supply and quality. }\end{array}$ \\
\hline $\begin{array}{l}\text { Type } \mathrm{V} \\
\left(\mathrm{X}_{2} \mathrm{Y}_{1} \mathrm{Z}_{1}\right) \\
\left(\mathrm{X}_{2} \mathrm{Y}_{1} \mathrm{Z}_{2}\right)\end{array}$ & $\begin{array}{l}\text { (1) Management strategy: minimization of management cost. } \\
\text { (2) Supplier relationship: general trade relationship. } \\
\text { (3) Performance evaluation criteria: suppliers develop and minimization of } \\
\text { purchase cost. }\end{array}$ \\
\hline $\begin{array}{l}\text { Type VI } \\
\left(\mathrm{X}_{1} \mathrm{Y}_{1} \mathrm{Z}_{1}\right) \\
\left(\mathrm{X}_{1} \mathrm{Y}_{1} \mathrm{Z}_{2}\right)\end{array}$ & $\begin{array}{l}\text { (1) Management strategy: flexible win-win strategy, ensure supply. } \\
\text { (2) Supplier relationship: cooperative partner, research and develop together to } \\
\text { improve product's green degree. } \\
\text { (3) Performance evaluation criteria: reliability of supply and accurate demand } \\
\text { calculation. }\end{array}$ \\
\hline
\end{tabular}

For situation of low product green degree or short of qualified supplier, the enterprise should try to develop suppliers. Managers should be aware of the strategic significance of suppliers developing. the mature new suppliers can break the supplier monopoly original. 


\section{Conclusion}

The efficiently Supplier management strategy can ensure the smooth operation of supply chain. It is particularly important to constitute supplier management strategy scientifically. For numerous suppliers, the enterprise should adopt different strategies. The paper analyzed materials from three dimensions, including cost value, purchase risk and product green degree. Based on the characteristics of materials, the suppliers are classified into six types. The supplier management strategy of each type was described in the paper, which can help the enterprise to improve the efficiency of supplier management Reference

\section{References}

[1] G. Svensson: Journal of Physical Distribution \& Logistics Management, Vol. 34 (2004) No.1, p.12-38

[2] J.H. Dyer, D.S Cho an W. Chu: California Management Review, Vol. 40 (2010) No.2, p.4-77

[3] R.F. Olsen and L.M. Ellram: Industrial Marketing Management, Vol. 26 (2007) No.7, p.101-103

[4] Y. Lin and S.H. Ma: Logistics Technology, Vol.25 (2010) No.5, p.30-32 (In Chinese)

[5] H.F. Zhang: Study on Supplier Classification Management in M Company (East China University of Science and Technology, China 2013), p.23.

[6] Y.H. Tao and Z.S. Yang: Machine, Vol.40 (2013) No.8, p.15-21

[7] S.Y. Xie: Research on Supplier Relationship Management of AD Co. Ltd. (Ms.D., South China University of Technology, China 2012), p.12.

[8] D.P. Wang, X. Wang and Y. Wang Yan: Research on technical economics and management, Vol. 39 (2009) No.1, p.41-43

[9] B. Pan: Electrician and electric, Vol. 22 (2013) No.2, p.48-51 (In Chinese)

[10]Y.H. Tao: Research and application on supplier evaluation in manufacturing supply chain (Ms.D., Chong Qing University, China 2013), p.22. 